\author{
Оксана Гнатів, \\ кандидат юридичних наук, доиент, \\ дочент кафедри циивільного права і процесу \\ Західноукраӥнського національного \\ університету \\ ORCID: https://orcid.org/0000-0002-0119-3508
}

\title{
Наталія Бутрин-Бока,
} кандидат юридичних наук, керівник Лабораторії сімейного права, доичент кафедри ичивільного права і прочесу Західноукраӥнського національного університету

ORCID: https://orcid.org/0000-0003-3684-7177

\author{
Ірина Базан, \\ студентка юридичного факультету \\ Західноукраӥнського національного \\ університету
}

\section{СКАСУВАННЯ ВИКОНАВЧОГО НАПИСУ НОТАРІУСА}

Представлено теоретико-правовий аналіз правової природи виконавчого напису нотаріуса, зокрема підстави, порядок, строки та проблеми його скасування. С формульовано об 'єктивні та суб 'єктивні передумови вчинення нотаріусом виконавчого напису. Під об'єктивними передумовами потрібно розуміти суспільні потреби у спрощеному порядку констатації і припинення безспірного правопорушення та усунення його наслідків, щзо має бути відтворено у процедурі вчинення нотаріусом виконавчого напису. Під суб 'єктивними передумовами вчинення виконавчого напису слід розуміти необхідність дотримання нотаріусом та особами, які звернулись за вчиненням нотаріальних дій, Правил посвідчення угод, передбачених Законом України «Про нотаріат». Підсумовано, щео у всіх відносинах щуодо виконавчих написів нотаріусів є підстави як для нотаріальних дій, так $і$ для діяльності суддів. У зв'язку з ичим наголошено, щзо надання нотаріусом виконавчої сили автентичному акту дає змогу звертати його до примусового виконання без звернення до суду. Такі дії нотаріуса не означають фактичного визнання юридичнӧ̈ вірогідності, безспірності чи інших суміжних ознак зобов'язань сторін, виражених у документі, на якому вчинено виконавчий напис.

Ключові слова: безспірність, боржник, стягувач, виконавчий напис, вимога, нотаріус, право, суд.

Гнатив О., Базан И.

Отмена исполнительной надписи нотариуса

Представлено теоретико-правовой анализ правовой природы исполнительной надписи нотариуса и, в частности, основания, порядок, сроки и проблемы его отмень. В работе сформулированы объективные и субъективные предпосылки совершения нотариусом исполнительной надписи. Под объективными предпосылками следует понимать общественные потребности в упрощченном порядке констатащии и прекращение бесспорного правонарушения и устранения его последствий, должно быть воссоздано в процедуре совершения нотариусом исполнительной надписи. Под субъективными предпосылками совершения исполнительной надписи следует понимать необходимость соблюдения нотариусом и лицами, которые обратились за совершением нотариальных действий, Правил удостоверение сделок, предусмотренньх Законом Украинь «О нотариате». Подведено, что во всех отношениях по исполнительных надписей нотариусов имеют место быть как для нотариальных действий, так и для деятельности судей. В связи с этим отмечается, что предоставление нотариусом исполнительной силь аутентичном акта позволяет обращать его к принудительному исполнению без обрашения в суд. При этом такие действия нотариуса не означают фактического признания юридической достоверности, бесспорности или иных смежных признаков обязательств сторон, выраженных в документе, на котором совершено исполнительную надпись.

(C) Оксана Гнатів, Наталія Бутрин-Бока, Ірина Базан, 2021 
Ключевые слова: бесспорность, должник, взыскатель, исполнительная надпись, требование, нотариус, право, суд.

\section{Gnativ O., Bazan I.}

\section{Cancellation of the notary's writ of execution}

The article presents a theoretical and legal analysis of the legal nature of the notaryss writ of execution and, in particular, the grounds, procedure, terms and problems of its cancellation. The paper formulates objective and subjective preconditions for a notary to perform an executive inscription. Objective preconditions should be understood as public needs in a simplified procedure for ascertaining and terminating an undisputed offense and eliminating its consequences, which should be reproduced in the procedure of making a notarized writ of execution. Subjective preconditions for the execution of a writ of execution should be understood as the need for the notary and persons who have applied for notarial acts to comply with the Rules of certification of agreements provided by the Law of Ukraine «On Notaries».

It is concluded that in all respects regarding the writs of execution of notaries there are grounds for both notarial acts and the activities of judges. In this regard, it is emphasized that the notarys enforcement of an authentic act allows it to be enforced without going to court. However, such actions of the notary do not mean the actual recognition of legal certainty, indisputability or other related features of the obligations of the parties, expressed in the document on which the writ of execution is made. Assessments of the legal qualities of the described type of obligations of the parties are presumed by the notary formally legally without recourse to the relevant procedures that make up civil and commercial litigation, leaving the interested parties the initiative to participate in these proceedings.

Keywords: indisputability, debtor, recoverer, executive inscription, demand, notary, law, court.

Постановка проблеми. Незважаючи на те, що Цивільний кодекс України був прийнятий понад сімнадцяти років тому (2004), ст. 18 якого у межах нотаріальної форми захисту порушених прав визначає єдиний спосіб - вчинення виконавчого напису питання правової природи виконавчого напису нотаріуса, а також процесуального порядку його вчинення і оскарження все ще недостатньо вивчені. Проблемні питання щодо оскарження виконавчого напису нотаріуса та сумніви щодо безспірності їх вчинення створюють прогалини у законодавстві, які потребують дослідження та удосконалення.

Поряд із наведеним тема набуває актуальності з огляду на те, що в процесі розгляду судами справ про визнання виконавчих написів такими, що не підлягають виконанню, як підтверджує практика, часто трапляються випадки недотримання нотаріусами вимог законодавства.

Аналіз останніх досліджень та публікацій. Теоретичне підгрунтя роботи становлять сучасне законодавства у сфері цивільного та нотаріального права і процесу, судова практика 3 дослідженої теми, а також праці вітчизняних вчених у сфері нотаріального та цивільного права і процесу, зокрема: А. Г. Серветник, Г. Д. Левин, О. Нелін, Ю. В. Желіховська, Т. Калиниченко, І. Неволіна. Використання теоретичних конструкцій, викладених у працях згаданих науковців, дало змогу сформулювати теоретичні підходи й сформувати власний погляд на питання щодо правової природи та особливості скасування виконавчого напису нотаріуса і його місця в системі способів захисту цивільних прав.

Виклад основного матеріалу дослідження. Питання скасування виконавчого напису нотаріуса доволі актуальне на сьогодні, адже проблема арешту майна на їх основі кредиторами без законних на те підстав поширюється. В цьому контексті доцільно зазначити, що вчинення нотаріусом виконавчого напису - це нотаріальна дія, що полягає в посвідченні права стягувача на стягнення грошових сум або витребування від боржника майна.

Відповідно до положень статті 87 Закону України «Про нотаріат», для стягнення грошових сум або витребування від боржника майна нотаріуси вчиняють виконавчі написи на документах, що встановлюють заборгованість [1].

Особливою ознакою виконавчого напису є те, що це виконавчий документ. Відповідна ознака виконавчого напису випливає не лише з теоретичних положень, а й зумовлена положеннями чинного законодавства. Зокрема, відповідно до п. 3 ч. 1 ст. 3 Закону України «Про виконавче провадження» виконавчий напис нотаріуса визначено як самостійний різновид виконавчого документа поряд із виконавчим листом, судовим наказом, ухвалою суду, посвідченням комісії з трудових спорів та ін. [12, с. 19].

На наше переконання, вчинення виконавчого напису змінює права та обов>язки, з чого виходить, що це також є правочином. Проте відома позиція, що виконавчий напис не є правочином. Поняття правочину надано в ч. 1 ст. 202 ЦК України: правочином є дія особи, спрямована на набуття, зміну або припинення цивільних прав та обов’язків. Згідно зі ст. 215 ЦК України поняття недійсності застосовується до правочинів [7]. Стаття 18 ЦК України встановлює, що вчинення виконавчого напису на борговому документі - це 
Цивільне право і цивільний процес. Сімейне право. Трудове право. Міжнародне приватне право. Господарське право. Господарсько-процесуальне право.

здійснення нотаріусом захисту цивільних прав, але підставою для вчинення виконавчого напису слугує правочин стягувача. Останній змінює таким чином відносини з боржником з добровільних на примусовий спосіб захисту власних прав. Тому, коли предметом спору є визнання виконавчого напису недійсним, такий предмет позову відповідає нормам цивільного та цивільного процесуального законодавства України, оскільки базується на правочині стягувача, посвідченому нотаріусом [6, с. 505]

Нотаріус здійснює свою діяльність у сфері безспірної юрисдикції. Він не встановлює прав або обов’язків учасників правовідносин, не визнає та не змінює їх, не вирішує питань права. У цій ситуації виконавчий напис не породжує права стягувача на стягнення грошових сум або витребування від боржника майна, а лише підтверджує, що таке право стягувач мав раніше. А от, чи дійсно таке право було, нотаріус має переконатися перед здійсненням виконавчого напису. Проте нотаріус вирішує питання про вчинення виконавчого напису за фактом подання документів, наданих лише однією стороною - стягувачем, таким чином подані документи згідно з відповідним переліком є підтвердженням безспірності заборгованості.

Зокрема, викладене вище декламує стаття 88 Закону України «Про нотаріат»: нотаріус вчиняє виконавчі написи, якщо подані документи підтверджують безспірність заборгованості або іншої відповідальності боржника перед стягувачем та за умови, що з дня виникнення права вимоги минуло не більше трьох років. Якщо для вимоги, за якою видається виконавчий напис, законом встановлено інший строк давності, виконавчий напис видається у межах цього строку [1].

Ознакою безспірності вимоги є відсутність заперечень боржника щодо заборгованості та їі розрахунку, а також відсутності будь-яких суперечностей у поданих документах. На підтвердження безспірності заборгованості нотаріусу мають бути подані документи, що свідчать про визнання боржником вимог кредитора. Як показує аналіз норм законодавства, указаних вище, нотаріус має впевнитися в розумінні боржником пред`явлених до нього вимог і визнанні їх. Документом, що підтверджує такий факт, можна вважати отримання боржником вимоги стягувача з підписом боржника про його отримання.

Як показує практика з порушення вимог закону, сьогодні ми спостерігаємо цілий потік незаконних нотаріальних написів на користь кредитних та колекторських компаній, які викупили за безцінь кредитні борги. На жаль, приватні нотаріуси ігнорують приписи законів, приймають в роботу прострочені кредитні вимоги, що призводить до незаконних стягнень та незаконних арештів майна. У деяких випадках також до безпідставної заборони на виїзд за межі України. Можливість оскарження виконавчого напису нотаріуса закріплено на законодавчому рівні. Вирішуючи спір про визнання виконавчого напису таким, що не підлягає виконанню, суд не повинен обмежуватися лише перевіркою дотримання нотаріусом формальних процедур і факту подання стягувачем документів на підтвердження безспірної заборгованості боржника згідно з Переліком. Для правильного застосування положень статей 87, 88 Закону України «Про нотаріат» у такому спорі суд повинен перевірити доводи сторін у повному обсязі й установити та зазначити в рішенні, чи справді на момент вчинення нотаріусом виконавчого напису боржник мав безспірну заборгованість перед стягувачем, тобто чи існувала заборгованість узагалі, чи була заборгованість саме такого розміру, як зазначено у виконавчому написі, та чи не було не вирішених по суті спорів щодо заборгованості або їі розміру на час вчинення нотаріусом виконавчого напису. Така правова позиція Великої Палати Верховного Суду викладена у постановах від 27 березня 2019 року у справі № 137/1666/16-ц (провадження № 14-84цс19), від 02 липня 2019 року у справі № 916/3006/17 (провадження № 14-278 гс18) та від 15 січня 2020 року у справі № 305/2082/14-ц (провадження № 14-557 цс 19) [2].

Щодо строків звернення кредитора (стягувача) до нотаріуса для вчинення виконавчого напису на борговому документі (ст. 88 Закону), то цікавою є позиція Великої Палати Верховного Суду. Як визначено в Законі, нотаріус вчиняє виконавчі написи за умови, що з дня виникнення права вимоги до боржника минуло не більше трьох років, а у відносинах між підприємствами, установами та організаціями - не більше одного року [1].

У своїй постанові від 2 липня 2019 р. Велика Палата Верховного Суду у справі № 916/3006/17 (провадження № 12-278гс18) зробила висновок, що строк для звернення до нотаріуса за вчиненням виконавчого напису безпосередньо пов'язаний із позовною давністю, встановленою Цивільним кодексом України. Таким чином, загальний строк для такого звернення становить три роки незалежно від суб'єктного складу сторін правовідносин, а якщо для вимоги, за якою видається виконавчий напис, законом встановлено іншу позовну давність, виконавчий напис видається у межах цього строку [3].

Законодавство не містить прямої вказівки на те, з якого моменту потрібно обраховувати річний або трирічний строк для вчинення виконавчого напису. Так, у ст. 88 Закону України «Про нотаріат» зазначається «день виникнення права вимоги», а в п. 3.4 глави 16 розділу II Порядку «день, коли у стягувача виникло 
право примусового стягнення боргу». Однак ні в першому, ні у другому випадку не можна робити висновок про однозначність положень нормативно-правових актів. Таким чином, з'ясувати, з якого моменту потрібно обраховувати строки, можна лише 3 комплексного аналізу законодавства. [4, с. 34]. Ще одна колізія в законодавстві стосується строків пред’явлення виконавчого напису до виконання. Відповідно до ч. 1 ст. 91 36МЕН № 3 (93), червень, 2017 р. Нотаріальний процес Закону України «Про нотаріат» виконавчий напис може бути пред'явлено до примусового виконання протягом одного року з моменту його вчинення [1]. Відповідно до ч. 1 ст. 12 Закону України «Про виконавче провадження» від 02.06.2016 року № 1404-VIII виконавчі документи можуть бути пред'явлені до примусового виконання протягом трьох років, крім посвідчень комісій з трудових спорів та виконавчих документів, за якими стягувачем є держава або державний орган, які можуть бути пред’явлені до примусового виконання протягом трьох місяців [5].

Однак із таким рішенням Великої Палати Верховного Суду важко погодитися, оскільки, нотаріус перш за все керується в своїй діяльності Законом України «Про нотаріат», а отже, оцінка його діяльності та законності його дій буде грунтуватись на Законі, а не на підставі постанови ВП ВС чи думці окремих суддів які плутають дотримання вимог Закону з власним бажанням його спотворити. Практика судів щодо визнання виконавчого напису нотаріуса таким, що не підлягає виконанню різноманітна, оскільки наявні прогалини в законодавстві, що зумовлює різне тлумачення норм закону. Так, Вищий господарський суд України у своїх постановах у справах про визнання виконавчого напису нотаріуса таким, що не підлягає виконанню, неодноразово вказував на те, що належними доказами, які можуть підтверджувати наявність чи відсутність заборгованості, а також встановлювати розмір зазначеної заборгованості, можуть бути тільки документи первинної бухгалтерської документації, оформлені відповідно до норм Закону України «Про бухгалтерський облік та фінансову звітність» - платіжні доручення, меморіальні ордери, розписки, чеки тощо [8].

Крім того, в постанові Вищого господарського суду України визначено, що безспірною заборгованістю є заборгованість боржника, з якою останній погоджується, що, відповідно, виключає можливість спору зі сторони боржника щодо іiі розміру, строку, за який вона нарахована, тощо, а відтак і документи, які підтверджують їі безспірність, і на підставі яких нотаріуси здійснюють виконавчі написи, мають бути однозначними, беззаперечними, та такими, що містять вираз волі щодо наявності певної заборгованості не тільки кредитора, а й самого боржника, або підтверджують наявність у боржника перед кредитором заборгованості саме в такому розмірі [9].

На нашу думку, основою вчинення нотаріальної дії є факт безспірності певної заборгованості, тому нотаріус не повинен переконуватися у безспірності розміру сум, що підлягають стягненню, тому що вчинення виконавчого напису - це не вирішення спору між кредитором і боржником, а підтвердження наявності заборгованості боржника з виконання грошового зобов'язання. Така позиція підтверджується ухвалами Вищого спеціалізованого суду України з розгляду цивільних та кримінальних справ, в якій суд дійшов висновку, що різниця в розмірі заборгованості на дату направлення позивачу вимоги та дати вчинення виконавчого напису нотаріуса пов'язана із завершенням строку, за який нараховані суми, передбачені кредитним договором, про що у вимозі банку позивача повідомляли [10].

Досліджуючи тематику статті, А. Г. Свертин зазначає, що можна виокремити найбільш поширені підстави для визнання виконавчого напису таким, що не підлягає виконанню, а саме: порушення порядку вчинення виконавчого напису - нотаріус вчинив виконавчий напис на підставі заяви без вказання строку, за який має провадитися стягнення щодо іпотечного договору; не надсилання вимоги стягувача - так, якщо стягнення відбувається за іпотечним договором. В разі порушення основного зобов'язання та / або умов договору вчинення виконавчого напису нотаріус здійснює після тридцяти днів з моменту надіслання кредитором та боржником письмової вимоги про усунення порушень. Якщо протягом встановленого строку вимога іпотекодержателя не задоволена, іпотекодержатель має право прийняти рішення про звернення стягнення на предмет іпотеки шляхом позасудового врегулювання на підставі договору; сплив строків давності - виконавчий напис можна вчинити, якщо $з$ дня виникнення права вимоги минуло не більше трьох років, а у відносинах між підприємствами, установами та організаціями - не більше одного року строк, пропущений строк стягувачем навіть 3 поважних причин, не може бути поновлений нотаріусом; неповнота та невідповідність законодавству документів, що були надані нотаріусу - нотаріус здійснив виконавчий напис на підставі документів, що не підтверджують безспірність; відсутність у змісті виконавчого напису відомостей, що передбачені законодавством, - нотаріус не зазначив обов'язкові відомості, передбачені законодавством України, наприклад дату, коли виконавчим напис набув чинності [11, с. 139$].$ 
Цивільне право і цивільний процес. Сімейне право. Трудове право. Міжнародне приватне право. Господарське право. Господарсько-процесуальне право.

Факт відсутності в українському законодавстві прямої норми, яка б регулювала порядок оскарження виконавчих написів нотаріуса, призводить до неоднакового вирішення справ судами України та перегляду таких рішень. Деякий час суди приймали заяви із різними позовними вимогами («визнати виконавчий напис нотаріуса недійсним», «скасувати виконавчий напис нотаріуса», «оскаржити виконавчий напис»). Але надалі в узагальненнях судової практики Вищих спеціалізованих судів та Верховного Суду України було роз'яснено, що недійсними в судовому порядку, відповідно до вимог Цивільного кодексу, можуть визнаватися правочини. Однак у процесі прийняття позовної заяви або скарги суди не можуть робити висновків щодо законності або незаконності вимог заявника, оскільки в такій ситуації це буде виявом їхньої упередженості. Пересічні громадяни мають право вимагати від суду законного рішення і за наявності підстав саме суд має кваліфікувати дії нотаріуса як законні або незаконні, а щодо визначення виконавчого напису нотаріуса, одночасно, як нотаріального акту, виконавчого документа та правочину стягувача, то це положення має синтезувати специфіку його багатоаспектності [11, ст. 141].

Висновки. Боржник може оскаржити вчинений нотаріусом виконавчий напис як 3 підстав порушення нотаріусом процедури вчинення виконавчого напису, так і з підстав неправомірності вимог стягувача (повністю або в частині розміру заборгованості, а також з підстав спливу строків позовної давності за вимогами в повному обсязі чи їхній частині). Нотаріальна дія або відмова у ії вчиненні можуть бути оскаржені до суду. Під час розгляду справи суд встановлює наявність безспірної заборгованості перед стягувачем на момент вчинення нотаріусом виконавчого напису. Тобто суд з>ясовує, чи була заборгованість, чи правильний розмір заборгованості та чи не було невирішених спорів щодо заборгованості або ііі розміру станом на час вчинення нотаріусом виконавчого напису. Обставини, які свідчать про наявність спору щодо заборгованості, суд встановлює відповідно до загальних правил цивільного процесу за наслідками перевірки доводів боржника та оцінки наданих доказів. Як інструмент захисту порушеного права виконавчий напис нотаріуса є окремою альтернативою судовому захисту, яка може застосовуватися у визначених законом випадках. Водночас суттєвою відмінністю виконавчого напису нотаріуса порівняно із судовою процедурою можна визнати те, що напис є більш оперативним способом захисту права, що надає кредитору переваги у вигляді скорочених строків розгляду, спрощеності процедури вчинення виконавчого напису та iii меншої формалізованості, а також вартості витрат, які несе сторона в процесі звернення до юрисдикційного органу.

\section{Список використаних джерел}

1. Про нотаріат : Закон України від 05.08.2021p. URL: https://zakon.rada.gov.ua/laws/show/3425-12\#Text (дата звернення: 02.09.2021).

2. Постанова Великої Палати Верховного Суду у справі № 137/1666/16-ц від 27 березня 2019 року (провадження № 14-84цс19). URL: https://reyestr.court.gov.ua/Review/80854768 (дата звернення: 02.09.2021).

3. Постанова Великої Палати Верховного Суду у справі № 916/3006/17 від 2 липня 2019 року. URL: https://reyestr.court.gov.ua/Review/82827046 (дата звернення: 04.09.2021).

4. Левченко А., Кирилюк Д. Проблемні аспекти вчинення виконавчих написів нотаріуса на договорах застави та іпотеки. Юридичний Радник. Київ, 2017. № 3(93). С. 29-38.

5. Про виконавче провадження : Закон України від 29.08.2021p. URL: https:/zakon.rada.gov.ua/laws/ show/1404-19\#Text (дата звернення: 03.09.2021p.).

6. Левин Г. Д. Три взгляда на природу теоретического и эмпирического знания. Вопросы философии. 2011. № 2. С. 104-115.

7. Цивільний кодекс України від 14.08.2021 p. URL: https://zakon.rada.gov.ua/laws/show/435-15\#Text (дата звернення: 02.09.2021).

8. Понамарьов Н. М., Косткіна Ю. О. Особливості розгляду господарськими судами спорів про визнання виконавчих написів такими, що не підлягають виконанню. Ужгород, 2012. № 20. URL: http:// artimmer.com/ua/publicacii/statti/77-osoblyvosti-rozglyadu-gospodarskymy-sudamy-sporiv-pro-vyznannyavykonavchyh-napysiv-notariusiv-takymy-scho-ne-pidlyagayut-vykonannyu (дата звернення: 04.09.2021).

9. Желіховська Ю. В. Стягнення заборгованості за векселями, опротестованими нотаріусами в установленому законом порядку. Мала енцииклопедія нотаріуса. 2011. № 4. С. 77-82.

10. Нелін О. Правова природа нотаріального акта в новітній парадигмі українського права. Юридична України. 2013. № 11. С. 4-8.

11. Серветник А. Г. Виконавчий напис нотаріуса як спосіб реалізації нотаріальної форми захисту цивільних прав : дисертація ... д-ра філософії: спец. 081 - Право. Київ, 2020. 232 с. 
12. Демченко О. Виконавчий напис нотаріуса як позасудова форма захисту цивільних прав та законних інтересів. Підприємництво, господарство і право. 2019. № 3. С. 15-19.

\section{References}

1. Pro notariat: Zakon Ukrainu vid 05.08.2021 roku [About the notary: Law of Ukraine of August 5, 2021$].$ Retrieved from https://zakon.rada.gov.ua/laws/show/3425-12\#Text [in Ukrainian].

2. Postanova Velukoi Palaty Verkhovnogo Sudu u spravi №137/1666/16-ų вid 27 bereznia 2019 roku (provadjenia № 14-84uc19) [Resolution of the Grand Chamber of the Supreme Court in case № 137/1666/16-u of March 27, 2019 (proceedings № 14-84tss19)]. Retrieved from https://reyestr.court.gov.ua/Review/80854768] [in Ukrainian].

3. Postanova Velukoi Palaty Verkhovnogo Sudu u spravi №916/3006/17 вid 2 lupnia 2019 roku. [Resolution of the Grand Chamber of the Supreme Court in case № 916/3006/17 of July 2, 2019]. Retrieved from https:// reyestr.court.gov.ua/Review/82827046 [in Ukrainian].

4. Levchenko, A. \& Kyryliuk, D. (2017). Problemni aspekty vchunennia vukonavchuh napusiv notariusa na dogovorah zastavu ta ipoteky [Problematic aspects of making notarial writs of execution on mortgage and mortgage agreements]. Yurydychnyi Radnyk - Legal Adviser, 3 (93), 29-38 [ in Ukrainian].

5. Pro vykonavche provadjenia: Zakon Ukrainu vid 29.08.2021 roku. [On enforcement proceedings: Law of Ukraine of August 29, 2021]. Retrieved from https://zakon.rada.gov.ua/laws/show/1404-19\#Text [in Ukrainian].

6. Levin, G. D. (2011). Tri vzgliada na teoriyu teoreticheskogo ta empericheskogo znania [Three views on the nature of theoretical and empirical knowledge]. Voprosy filosofi-Questions of philosophy, 2, 104-115.

7. Tsuvilnyi kodecs Ukrainy vid 14.08.2021 roku [Civil Code of Ukraine of August 14, 2021]. Retrieved from https://zakon.rada.gov.ua/laws/show/435-15\#Text [ in Ukrainian].

8. Ponamarov, N. M. \& Kostkina, U. O. (2012). Osobluvosti rozhliadu gospodarskymy sudamy sporiv pro vyznania vykonavchyh nadpysiv takymy, shcho ne pidliagayt vykonaniu [Peculiarities of consideration by commercial courts of disputes on recognition of writs of execution as non-enforceable]. Uzhhorod, 2012. №20. Retrieved from http://artimmer.com/ua/publicacii/statti/77-osoblyvosti-rozglyadu-gospodarskymysudamy-sporiv-pro-vyznannya-vykonavchyh-napysiv-notariusiv-takymy-scho-ne-pidlyagayut-vykonannyu [in Ukrainian].

9. Zhelihovska, U. V. (2011). Stiagnenia zaborgovanosti za vekseliamu, oprotestovanymy notariusamy v vstanovlenomy zakonom poriadky [Debt collection on promissory notes protested by notaries in the manner prescribed by law]. Mala entsyclopedia notariusa - A small encyclopedia of a notary, 4, 77-82 [in Ukrainian].

10. Nelin, O. (2013). Pravova pryroda notarialnogo akta v novitniy paradygmi ukrainskogo prava [The legal nature of the notarial act in the latest paradigm of Ukrainian law]. Pravova Ukraina - Legal of Ukraine, 11, 4-8 [in Ukrainian].

11. Svertnyk, A. G. (2020). Vykonavchyi napys notariusa yak sposib realizacii notarialnoi formy zahusty cuvilnyh prav [The executive inscription of the notary as a way of realization of the notarial form of protection of civil rights]: dis. ... doctora filosofii: spets 081 - Pravo. Kyiv, 2020 [in Ukrainian].

12. Demchenko, O. (2019). Vykonavchyy napys notariusa yak pozasydova forma zahusty cuvilnyh prav ta zakonnuh interesiv [Notary's writ of execution as an extrajudicial form of protection of civil rights and legitimate interests]. Pidpryemnytstvo, hospodarstvo i pravo - Entrepreneurship, economy and law. Zaporozhye, 3, 15-19 [in Ukrainian]. 